\title{
HUBUNGAN KEPERCAYAAN DAN PELAYANAN DENGAN KEPUTUSAN MENGGUNAKAN JASA CV. RAFELINDOTOUR AND TRAVEL BENGKULU
}

\author{
Tito Irwanto, Karona Cahya Susena, Putri Ramaddan \\ Program Studi Manajemen Fakultas Ekonomi Universitas Dehasen Bengkulu \\ tito.irwanto22@gmail.com
}

\begin{abstract}
ABSTRAK
Tito Irwanto, Karona Cahya Susena, Putri Ramaddan; Tujuan Penelitian ini untuk mengetahui hubungan kepercayaan dan pelayanan dengan keputusan menggunakan jasaCV. Rafelindo tour and travel Bengkulu. Metode pengumpulan data menggunakan kuisioner dan metode analisis menggunakan korelasi rank spearman dan uji hipotesis. Sampel dari penelitian ini adalah 100 orang konsumen yang membeli tiket yang beralamatkan di Jl. Cempaka No.007 RT/TW 007/003 Kel. Kebun Beler Kec. Ratu Agung.

Berdasarkan hasil penelitian korelasi rank spearman kepercayaaan memiliki korelasi sebesar 0,467 dengan criteria penilaian sedang dan pelayanan memiliki korelasi sebesar 0,602 dengan criteria penilaian kuat. Hal ini menunjukan bahwa pelayanan sangat berhubungan dengan keputusan pembelian, yang artinya semakin meningkatnya pelayanan yang dilakukanCV. Rafelindo tour and travel Bengkulu semakintinggi pula keputusan menggunakan jasa pada CV. Rafelindo tour and travel Bengkulu. Hasil uji

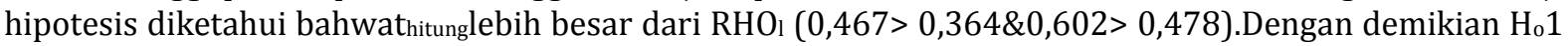
\& $\mathrm{H}_{0} 2$ ditolak dan $\mathrm{H}_{\mathrm{a}} 1 \& \mathrm{H}_{\mathrm{a}} 2$ diterima.Artinya kepercayaan dan pelayanan mempunyai hubungan yang signifikan dengan keputusan menggunakan jasa di CV. Rafelindo tour and travel Bengkulu.
\end{abstract}

\section{ABSTRACT}

Tito Irwanto, Karona Cahya Susena, Putri Ramaddan; The purpose of this study was to determine the relationship of trust and service with the decision to use the services of CV. Rafelindo tour and travel Bengkulu. Methods of data collection using questionnaires and analytical methods using Spearman rank correlation and hypothesis testing. The sample from this study was 100 consumers who bought tickets that were addressed at Jl. Cempaka No.007 RT / TW 007/003 Kel. KebunBelerKec.The Great Queen.

Based on the results of the research the Spearman rank correlation of trustees has a correlation of 0.467 with the criteria of moderate assessment and service having a correlation of 0.602 with strong assessment criteria. This shows that the service is very much related to purchasing decisions, which means that the services that CV. Rafelindo tour and travel Bengkulu is getting higher, the decision to use services on CV. Rafelindo tour and travel Bengkulu. Hypothesis test results are known that tcount is greater than RHOl (0.467> 0.364 \& $0.602>0.478)$. Thus Ho1 \& Ho2 are rejected and H1a1 \& Ha2 are accepted. This means that trust and service have a significant relationship with the decision to use services on the CV. Rafelindo tour and travel Bengkulu.

Key Words: Trust and services

\section{LATAR BELAKANG}

Seperti kita ketahui bahwa kemajuan teknologi berdampak besar terhadap bidang jasa perjalanan umumnya transportasi udara, transportasi udara berkembang sangat pesat mulai dari booking manual via online sampai biro jasa travel agent yang membuat konsumen mempunyai banyak pilihan, tidak hanya pilihan bahkan konsumen bisa memilih pelayanan sesuai dengan yang mereka inginkan, dan untuk sekarang konsumen lebih memillih travel online karena travel online lebih praktis dan terkadang harganya lebih murah di bandingkan dengan travel agent.

Seiring dengan semakin meningkatnya jumlah permintaan maka intensitas penerbangan pun ikut meningkat. Tentu saja dengan peningkatan permintaan tersebut perlu di ikuti juga dengan peningkatan pelayanan terhadap setiap penerbangan, seperti halnya informasi pelayanan/pemesanan tiket. Hal ini sangat penting karena menyangkut pelayanan terhadap konsumen. Dengan adanya informasi yang benar tentang pelayanan tiket akan mempermudah konsumen dalam proses booking.

Salah satu perusahaan biro jasa perjalanan transportasi udara yang ada di Kota Bengkulu adalah CV. RAFELINDO TOUR AND TRAVEL BENGKULU merupakan perusahaan swasta yang bergerak dalam bidang biro jasa pembelian ticketing transportasi udara atau pesawat udara.

Sampai saat ini tahun 2018 CV. Rafelindo Tour and Travel Bengkulu berkembang dan melakukan berbagai inovasi dan sudah memiliki contract rate dengan berbagai maskapai seperti, Lion air, Wings air, 
Batik air, Citilink, Sriwijaya air, Nam air dan Garuda Indonesia Dengan adanya conract rate ini dapat mempermudah pelanggan memilih jasa merek mana yang mereka inginkan dan pelayanan seperti apa yang mereka dapatkan dari maskapai, seperti Garuda indonesia dengan pelayanan berbintang dapat memberikan kenyamanan terhadap pelanggan, sedangkan lion air yang menawarkan banyaknya schedule penerbangan dan pelanggan pun bebas memilih jam penerbangan tersebut. Pada penelitian ini, peneliti akan menganalisa hubungan kepercayaan dan pelayanan dengan keputusan menggunakan jasa CV. Rafelindo tour and travel Bengkulu

\section{LANDASAN TEORI}

\section{Kepercayaan Konsumen}

Menurut Jasfar (2010:181), kepercayaan adalah keinginan untuk mempercayai pihak lain di mana dia saling berhubungan atau harapan seorang bahwa kata-kata pihak lain dapat dipercaya. Sedangkan menurut Robbins (2011:59), kepercayaan adalah sebagai ekpektasi atau pengharapan positif bahwa orang lain tidak akan bertindak secara oportunistik, baik secara kata-kata, tindakkan dan kebijakkan.

Dari beberapa definisi tersebut dapat disimpulkan bahwa kepercayaan adalah kesediaan konsumen untuk menggunakan jasa perusahaan karena yakin bahwa perusahaan mempunyai kehandalan untuk mampu menepati janji yang diberikan kepada konsumen sehingga nantinya membentuk loyalitas konsumen.

\section{Pelayanan}

Menurut Moenir (2010:47), pelayanan adalah proses pemenuhan kebutuhan melalui aktivitasaktivitas orang lain secara langsung. Pelayanan berarti prilaku para kariawan CV. Rafelindo tour and travel Bengkulu terhadap pelanggannya, dimana kewajiban keryawan terhadap pelanggannya adalah sebagai berikut (Moenir 2010:47):

1. Bersikap sopan santun, ramah dan hormat tanpa merendahkan diri.

2. Berlaku jujur dan adil, tidak membeda-bedakan dalam hal pelayanan.

3. Menghormati pendapat dan perasaan pelanggan dengan cara mendengarkan keluhan dan keinginan dengan sabar.

4. Menyimpan dengan baik rahasia jabatan ( misalnya : aib seorang langganan) atau rahasia pribadi pelanggan

5. Menepati janji yang telah di buat dengan pelanggan.

6. Mengadakan percakapan yang masuk akal, yang bermakna, sopan santun dan patut.

American management association memberikan definisi terhadap pelayanan adalah sebuah kegiatan, keuntungan, atau kepuasan yang ditawarkan untuk dijual atau di sediakan dan berkaitan dengan penjualan barang-barang. Contoh dari pelayanan yaitu hotel, taman bermain, transportasi dan lain sebagainya.

\section{Jasa}

Pengertian jasa menurut sunyoto, (2012) jasa adalah setiap tindakkan atau kegiatan yang dapat ditawarkan oleh satu pihak ke pihak lain, pada dasarnya tidak berwujud dan tidak mengakibatkan kepemilikan apapun. Produksi jasa bisa berkaitan dengan produk fisik atau sebaliknya dan jasa memiliki karakteristik tertentu.

Tjiptono dan Chandra (2011) menjelaskan jasa (service) sebagai kegiatan yang dapat di identifikasi secara tersendiri yang pada hakekatnya bersifat tidak meraba (intangible) yang merupakan pemenuhan kebutuhan dan tidak harus terikat pada penjualan produk / jasa lain.

Definisi tersebut menunjukkan bahwa di dalam jasa atau pelayanan selalu dijumpai adanya aspek interaksi yang terjadi antara pihak konsumen adalah penyedia jasa, meskipun pihak - pihak yang terlibat tersebut seringkali tidak menyadari, jasa juga bukan merupakan barang, jasa adalah suatu proses aau aktivitas, dan aktivitas tersebut tidak berwujud. Jasa atau pelayanan mempunyai empat karakteristik utama yang sangat mempengaruhi pemasaran (Kotler, 2014).

a. Intangible (tidak berwujud)

Jasa mempunyai sifat tidak berwujud, tidak dapa dirasakan dan dinikmati sebelum di beli oleh konsumen. Untuk mengurangi ketidak pastian, konsumen akan mencari tanda atau bukti dari 
kualitas jasa. Konsumen akan menarik kesimpulan mengenai kualitas jasa dari tempat, orang, peralatan, alat komunikasi dan harga yang mereka lihat.

b. Inseparability (tidak dapat dipisahkan)

Jasa di produksi (dihasilkan) dan dirasakan pada waktu yang bersamaan. Dikarnakan konsumen juga hadir saat suatu jasa dilakukan, interaksi penyedia konsumen merupakan ciri khusus pemasaran jasa.

c. Variability (bervariasi)

Jasa sangat bervariasi, tergantung dari siapa yang menghasilkan jasa, kapan dan dimana jasa tersebut diberikan.

d. Perishability ( tidak tahan lama )

Jasa tidak dapat disimpan. Sifat jasa yang tidak tahan lama tersebut bukan menjadi masalah apabila permintaan tetap. Namun jika permintaan berfluktasi, perusahaan jasa menghadapi masalah yang rumit. Misalnya, sebuah perusahaan transportasi umumnya harus memiliki banyak kendaraan karena adanya permintaan pada jam sibuk, dibandingkan jika permintaan cukup merata sepanjang hari

\section{Pengambilan Keputusan Pembelian}

Menurut Fahmi (2012:56), keputusan adalah proses penelusuran masalah yang berawal dari latar belakang masalah, identifikasi masalah hingga kepada terbentuknya kesimpulan atau rekomendasi. Rekomendasi itulah selanjutnya dipakai dan digunakan sebagai pedoman basis dalam pengambilan keputusan. Keputusan konsumen merupakan tindakkan konsumen dalam memutuskan sebuah produk yang di anggap menjadi solusi dari kebutuhan dan keinginan konsumen tersebut.

Menurut Kotler \&Armstrong (2013:158), keputusan pembelian adalah pemilohan dari dua atau lebih alternatif pilihan keputusan pembelian artinya seseorang dapat membuat keputusan, harus tersedia beberapa alternatif pilihan. Keputusan pembelian menurut Nugroho (2010:38) adalah proses pengintegrasian yang mengkombinasi sikap pengetahuan untuk mengevaluasi dua atau lebih prilaku alternatif dan memilih salah satu di antaranya.

Dari beberapa definisi di atas dapat di simpulkan bahwa pengambilan keputusan merupakan suatu proses pemilihan salah satu dari beberapa alternatif penyelesaian masalah dengan tindak lanjut yang nyata. Setelah itu konsumen dapat melakukan evaluasi pilihan dan kemudian dapat menentukan sikap yang akan di ambil.

\section{KERANGKA ANALISIS}

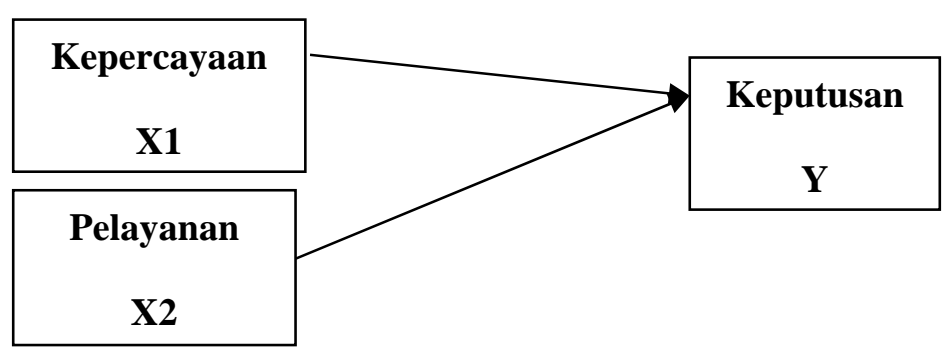

Gambar 1. Kerangka Penelitian

\section{HASIL DAN PEMBAHASAN}

Penelitian ini menggunakan metode survey dengan mengambil sampel dari satu populasi dengan menggunakan kuesioner sebagai alat pengumpulan data yang pokok (Singarimbun, 2010:3), penyebaran kuesioner di tujukan kepada sampel penelitian melalui penelitian ini di harapkan dapat memberikan gambaran yang jelas mengenai hubungan kepercayaan konsumen dan pelayanan dengan keputusan menggunakan jasa CV. Rafelindo tour and travel bengkulu.

Sampel dalam penelitian ini di ambil dengan teknik adjusment sampling sebanyak 100 orang yang berasal dari pelanggan atau pengunjung yang menggunakan jasa CV. Rafelindo tour and travel Bengkulu. Menurut Sugiyono (2017:162) teknik adjusment sampling adalah teknik pengambilan sample yang di tentukan dengan menyesuaikan pada tujuan penelitian atau pertimbangan tertentu. Jadi metode yang digunakan adalah metode Rank Spearman dan Uji Hipotesis 
Tabel 1. Karakteristik Responden Berdasarkan Jenis Kelamin

\begin{tabular}{|c|c|c|}
\hline Jenis Kelamin & Jumlah (Orang) & Persentase(\%) \\
\hline Perempuan & 18 & $60 \%$ \\
\hline Laki-Laki & 12 & $40 \%$ \\
\hline Jumlah & 30 & $100 \%$ \\
\hline
\end{tabular}

Sumber : Hasil Kuesioner, 2018

Berdasarkan jenis kelamin dari tabel di atas maka dapat diketahui bahwa konsumen yang menggunakan jasa CV. Rafelindo tour and travel Bengkulu yang paling banyak adalah perempuan yaitu sebanyak 18 orang atau 60\% ini dikarnakan besarnya minat travelling pada zaman sekarang untuk menjelajah tempat-tempat yang unik, berbelanja dan perjalanan tour wisata, dan laki-laki di posisi terendah dengan 12 orang atau 40\% ini dikarenakan laki-laki berpergian hanya karena perjalanan dinas luar.

Tabel 2. Karakter Responden Berdasarkan Umur

\begin{tabular}{|c|c|c|}
\hline Umur & Jumlah (Orang) & Persentase(\%) \\
\hline $17-30$ & 22 & $73 \%$ \\
\hline $31-45$ & 8 & $26 \%$ \\
\hline Jumlah & 30 & $100 \%$ \\
\hline
\end{tabular}

Sumber : Hasil Kuesioner, 2018

Berdasarkan tabel 4 maka dapat diketahui bahwa mayoritas konsumen yang menggunakan jasa tour and travel pada CV. Rafelindo tour and travel Bengkulu adalah konsumen dengan latar belakang usia dalam rentang 17-30 tahun sebesar 73\% dan diikuti dengan konsumen dengan rentang usia 31-45 tahun sebesar $26 \%$ dari tabel diatas maka sebagian besar konsumennya adalah berusia lebih muda, itu karena sekarang mereka lebih memilih mendapatkan pelayanan, harga yang lebih murah dan menghemat waktu perjalanan mereka lebih banyak waktu untuk melakukan perjalanan mengisi waktu luang dengan study tour ataupun berpergian untuk belanja.

Tabel 3. Karakteristik Responden berdasarkan Pendidikan

\begin{tabular}{|c|c|c|}
\hline Pendidikan & Jumlah (Orang) & Persentase (\%) \\
\hline SMP & 1 & $3,3 \%$ \\
\hline SMA & 18 & $60 \%$ \\
\hline D3 & 3 & $10 \%$ \\
\hline S1 & 6 & $20 \%$ \\
\hline S2 & 2 & $6,6 \%$ \\
\hline Jumlah & 30 & $100 \%$ \\
\hline
\end{tabular}

Sumber : Hasil Kuesioner, 2018

Berdasarkan tingkat pendidikan dari tabel 5, dapat diketahui bahwa tingkat pendidikan yang paling banyak SMA yaitu sebesar 60\% karena mereka biasanya lebih menjaga gengsi.

\section{Pembahasan}

Berdasarkan pengujian analisis rank spearman dan uji hipotesis maka didapatkan hasil dari pengujian tersebut seperti tabel di bawah ini

Tabel 9. Hasil pengujian korelasi Rank Spearamn dan uj hipotesis kepercayaan( $\left.\mathrm{X}_{1}\right)$ dengan keputusan menggunakan jasa (Y)

\begin{tabular}{|l|l|l|l|l|}
\hline No & Variabel & P & Ket & Nilai Signifikan \\
\hline 1 & Kepercayaan & 0,467 & Sedang & 0,002 \\
\hline 2 & Pelayanan & 0,602 & Kuat & 0,001 \\
\hline
\end{tabular}

Sumber : Data diolah, 2018

Berdasarkan tabel di atas penelitian dari oengujian korelasi rank spearman menggunakan SPSS pada variabel Kepercayaan $\left(\mathrm{X}_{1}\right)$ dengan keputusan menggunakan pembelian ( $\mathrm{Y}$ ) dapat diketahui bahwa 
kepercayaan memiliki hubungan yang signifikan dengan keputusan menggunakan jasa pada CV. Rafelindo tour and travel Bengkulu dengan nilai korelasi rank spearman 0,467. Hasil ini diperkuat dengan hasil uji hipotesis bahwa rho hitung lebih besar dari rho tabel $(0,467>0,364)$ hal ini diperkuat dengan hasil pengujian hipotesis diketahui nilai signifikan sebesar 0,002 $<0,05$. Dengan demikian hasil uji hipotesis adalah Ho1 di tolak dan Ha1 di terima. Artinya kepercayaan memiliki hubungan yang signifikan dengan keputusan menggunakan jasa CV. Rafelindo tour and travel Bengkulu.

Hasil penelitian ini sesuai dengan pendapat Menurut Jasfar (2010:181), kepercayaan adalah keinginan untuk mempercayai pihak lain di mana dia saling berhubungan atau harapan seorang bahwa kata-kata pihak lain dapat dipercaya. Hal ini menjelaskan bahwa kepercayaan memberikan pengaruh dalam mengambil keputusan menggunakan jasa.

Jasa (service) sebagai kegiatan yang dapat di identifikasi secara tersendiri yang pada hakekatnya bersifat tidak meraba (intangible) yang merupakan pemenuhan kebutuhan dan tidak harus terikat pada penjualan produk / jasa lain.

Berikutnya adalah berdasaarkan hasil uji korelasi rank spearman menggunakan SPSS pada variabel pelayanan $\left(\mathrm{X}_{2}\right)$ dengan keputusan menggunakan jasa (Y) maka diuji analisis diketahui bahwa rho hitung lebih besar dari tabel rho $(0,602>0,478)$ sehingga Ho1 ditolak Ha2 diterima artinya terdapat hubungan yang signifikan antara pelayanan dengan keputusan menggunakan jasa pada CV. Rafelindo tour and travel Bengkulu. Dari hasil pengujian rank spearman terdapat hubungan yang kuat antara pelayanan dengan keputusan menggunakan jasa pada CV. Rafelindo tour and travel Bengkulu dengan nilai korelasi sebesar 0,602 . Hal ini diperkuat dengan hasil pengujian hipotesis diketahui nilai signifikan sebesar 0,001<0,05 artinya pelayanan memiliki hubungan yang signifikan dengan keputusan menggunakan jasa pada CV. Rafelindo tour and travel Bengkulu.

Hasil penelitian ini sesuai dengan pendapat Menurut Suparlan (2010:35), pelayanan adalah usaha pemberian bantuan atau pertolongan kepada orang lain, baik berupa materi maupun non materi agar orang dapat mengatasi masalahnya sendiri. Pelayanan berarti prilaku para kariawan CV. Rafelindo tour and travel Bengkulu terhadap pelanggannya, dimana kewajiban keryawan terhadap pelanggannya yang selalu dijumpai adanya aspek interaksi yang terjadi antara pihak konsumen sebuah kegiatan, keuntungan, atau kepuasan yang ditawarkan untuk dijual atau di sediakan dan berkaitan dengan penjualan barangbarang sehingga konsumen tertarik untuk menggunakan jasa pada CV. Rafelindo tour and travel Bengkulu.

\section{Kesimpulan}

Dari hasil penelitian dan pembahasan tentang hubungan kepercayaan dan pelayanan dengan keputusan menggunakan jasa pada CV. Rafelindo tour and travel Bengkulu dapat disimpulkan sebagai berikut:

1) Dari hasil korelasi rank spearman nilai rho hitung ( $p$ ) pada hubungan kepercayaan dengan keputusan menggunakan jasa pada CV. Rafelindo tour and travel Bengkulu adalah 0,467 dan berada pada interval 0,400 - 0,599 (keriteria sedang), ini artinya variabel kepercayaan memiliki hubungan yang signifikan terhadap variabel keputusan menggunakan jasa pada CV. Rafelindo tour and travel Bengkulu. Berdasarkan hasil perhitungan pada uji korelasi nilai rho hitung (p) sebesar 0,467 sedangkan rho tabel 0,364 (terlampir) atau 0,467 > 0,364 sehingga Ho1 ditolak dan Ha1 diterima artinya ada hubungan yang signifikan antara kepercayaan dengan keputusan menggunakan jasa pada CV. Rafelindo tour and travel Bengkulu.

2) Dari hasil rank spearman nilai rho hitung $(p)$ pada hubungan variabel pelayanan dengan keputusan menggunakan jasa pada CV. Rafelindo tour and travel Bengkulu sebesar 0,602 berada pada interval 0,600-0,799, artinya hubungan antara variabel pelayanan dengan keputusan menggunakan jasa pada CV. Rafelindo tour and travel Bengkulu adalah kuat. Berdasarkan hasil perhitungan pada uji kolersi nilai rho hitung (p) sebesar 0,602 sedangkan rho tabel 0,364 (terlampir) atau 0,602>0,364 sehingga Ho2 ditolak dan Ha2 diterima artinya ada hubungan yang signifikan antara promosi dengan keputusan menggunakan jasa pada CV. Rafelindo tour and travel Bengkulu.

\section{Saran}

Berdasarkan kesimpulan dari hasil penelitian diatas, maka disarankan kepada kantor CV. Rafelindo tour and travel Bengkulu untuk diperhatikan dan ditingkatkan adalah :

1. Ditingkatkan lagi terutama dalam kepercayaan karena dalam jenis bisnis apapun, membangun kepercayaan merupakan kunci sukses untuk meraih keberhasilan. Tidak peduli apakah bisnis 
tersebut berskala besar atau kecil, kepercayaan dibutuhkan untuk terus menumbuhkan dan mengembangkan bisnis.

2. Membangun kepercayaan merupakan salah satu upaya untuk meraih tujuan-tujuan bisnis yang lain. Misalnya saja dengan membangun kepercayaan kepada konsumen, mereka akan dengan senang hati menggunakan produk atau layanan yang ditawarkan, sehingga konsumen dapat merekomendasikan kepada orang lain untuj menggunakan jasa pada CV. Rafelindo tour and travel Bengkulu sebagai jasa tour and travel.

\section{DAFTAR PUSTAKA}

Fahmi, Irham 2012. Metide Penelitian Administrasi. Alfabeta. Bandung. Jasfar, Farida. 2010. Manajemen Jasa Pendekatan Terpadu. Ghalia Indonesia. Bogor.

Kotler 2014. Manajemen Pemasaran. Edisi ketigabelas.erlangga. Jakarta

Kotler, Philip dan Armstrong, Gery. 2013. Dasar-dasar Pemasaran. Jilid 2. PT. Indeks. Jakarta.

Moenir. 2010. Manajemen Pelayanan Umum di Indonesia. Bumi Aksara. Jakarta.

Sugiyono.2010. Metode Penelitian Bisnis. Alfabeta. Bandung.

Sugiyono, 2011. Metode Penelitian Administrasi. Alfabeta. Bandung.

Sugiyono, 2009. Metode Penelitian Administrasi. Alfabeta. Bandung

Sunyoto, Dadang. 2012. Dasar-dasar Manajemen Pemasaran. CAPS. Yogyakarta.

Tjiptono, 2012. Manajemen Pemasaran. Andi. Yogyakarta.

Tjptono, Chandra. 2012. Pemasaran strategik. Andi. Yogyakarta 